\title{
Hereditary Hemorrhagic Telangiectasia or Osler-Weber -Rendu Syndrome: Management of Epistaxis in 4 Cases.
}

\author{
Salina $\mathrm{H}^{\mathrm{a}}$, Lim PS ${ }^{\mathrm{a}}$, Gendeh $\mathrm{BS}^{\mathrm{a}}$
}

${ }^{a}$ Department of Otorhinolaringology-Head and Neck Surgery, Faculty of Medicine, UKM Medical Centre, The National University of Malaysia, Malaysia

\begin{abstract}
Hereditary Hemorrhagic Telangiectasia, also known as Osler-Weber-Rendu Syndrome is an autosomal dominant disorder causing systemic abnormalities of the vascular structure. There are multiple arteriovenous malformations present in the skin and mucosal surface of the nail beds, nose, gastrointestinal tract, lungs and brain. Epistaxis is the common presentation symptom, which may require multiple hospital admissions and blood transfusions. It is extremely rare disease in our population. We report 4 cases of HHT who presented to us with moderate to severe epistaxis and how we managed these patients.
\end{abstract}

KEYWORDS: HHT, epistaxis, electrocautery, septodermoplasty

\section{INTRODUCTION}

Hereditary Hemorrhagic Telangiectasia (HHT) is an autosomal dominant inherited disorder that affects the vascular structures of the whole body. It had an overall prevalence of 1 in 5000 to 8000 with regional variability. ${ }^{1}$ It is characterized by recurrent epistaxis, mucocutaneous telangiectasia and visceral arteriovenous malformation and may be life threatening depending on site and severity of bleeding. The underlying cause of the disease is due to lack muscle and elastic tissue in the blood vessel wall. Following the telangiectasia damage, the blood vessel is not capable to constrict resulting in profuse bleeding. About $80-90 \%$ of HHT patients presented with epistaxis. They can have some other problems like haematemesis, haemoptysis, heavy menstrual bleeding intracranial haemorrhage or even brain abscess. Telangiectasias can occur anywhere in the body mainly on the tongue, oral cavity, stomach and lungs and skin of the face, lips

Corresponding Author:

Associate Professor Dr. Salina Husain

Department of Otorhinolaryngology-

Head and Neck Surgery,

Faculty of Medicine, UKM Medical Centre, The National University of Malaysia, Malaysia

Tel: +60391455555, Fax: +60391456675,

email:drsalina_h@yahoo.com ears, fingers and nail beds. HHT is diagnosed based on Curacao criteria: presence of recurrent epistaxis, telangiectasia spots, evidence of autosomal dominant and visceral AVMs.

We report 4 cases of HHT who predominantly presented with epistaxis and how we managed these patients.

\section{MATERIALS AND METHOD}

This is a retrospective review of all patients who were diagnosed to have Hereditary Haemorrhagic Telangiectasia from 1997 to 2015 at Otorhinolaryngology clinic, Universiti Kebangsaan Malaysia Medical Centre. A total of 4 patients were included in the study.

\section{Case Report 1}

A 60-year-old female presented with history of recurrent moderate to severe epistaxis for 20 years. She had underlying rheumatoid arthritis, Hepatitis B and bilateral knee osteoarthritis. On examination, there were multiple telangiectasias over septal mucosa, turbinate and nasopharynx. There was also other mucocutaneous telangiectasia over her skin and tongue. She was also noted to have telangiectasia spots in her stomach on 
oesophagoduodenoscopy (OGDS). Computed tomography (CT) of thorax showed no evidence of pulmonary arteriovenous malformation. She was an adopted child so we was unable to trace back her biological family to look for the presence of HHT in her family. Over the years her epistaxis progressively get worsened and she was admitted once for blood transfusion. We performed electrocauterization of prominent telangiectasia over her nasal mucosa using bipolar diathermy. Since then she was well with mild epistaxis and stable with hemoglobin level above $11 \mathrm{~g} / \mathrm{dL}$ to date.

\section{Case Report 2}

A 58-year-old male had a history of recurrent epistaxis for 25 years. Endoscopic examination revealed multiple telangiectasias on the septum and inferior turbinates. There was also other mucocutaneous telangiectasia over the skin and tongue. His mother and his two male siblings also had similar symptoms of recurrent epistaxis. OGDS revealed multiple telangiectasia spots over the fundus and antrum of his stomach. CT thorax showed normal findings. Blood investigation revealed an iron deficiency anemia. The telangiectasia spots over his nasal mucosa were electro-cauterized using bipolar diathermy. He had one episode of upper gastro-intestinal tract bleeding requiring blood transfusion and endoscopic clipping of bleeding spots. Apart from this bleeding episode, he is stable on follow up with minimal mild epistaxis.

\section{Case Report 3}

A 65-year-old man had been suffering from recurrent epistaxis for 29 years. He had a strong family history of recurrent epistaxis (mother and younger brother). He was diagnosed to have HHT and open left septodermoplasty was performed in other hospital 10 years ago. He had mild recurrent of epistaxis after the procedure. On examination, multiple telangiectasias noted over his nasal mucosa in the septum and turbinates with crusting over the left nasal septum (previous septodermoplasty site). There was also other mucocutaneous telangiectasia over his skin and tongue. OGDS and CT thorax revealed normal study.

\section{Case Report 4}

A 69-year-old man presented with a 30 year-history of recurrent epistaxis. On examination, there were multiple telangiectasias seen on the mucosa of nasal cavities. There was also other mucocutaneous telangiectasia over his skin and tongue. OGDS revealed multiple telangiectasia spots over the antrum of his stomach. CT thorax was normal findings. He had recurrent epistaxis and was treated with electro-cauterization. He had septodermatoplasty done in 2006. In April 2009, he presented with left epistaxis with symptomatic anaemia requiring blood transfusion. Left septodermatoplasty was performed using buccal mucosa. Epistaxis was reduced in frequency and severity after the procedure. In March 2010, he developed epistaxis requiring blood transfusion and electro-cauterization using bipolar diathermy was performed. Since then he is having mild epistaxis without requiring blood transfusion or any surgical interventions.

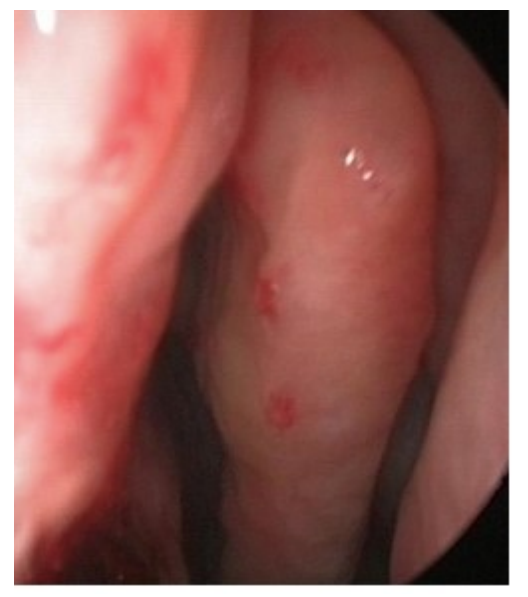

Figure 1: The presence of multiple telangietatic spots on the left middle turbinate

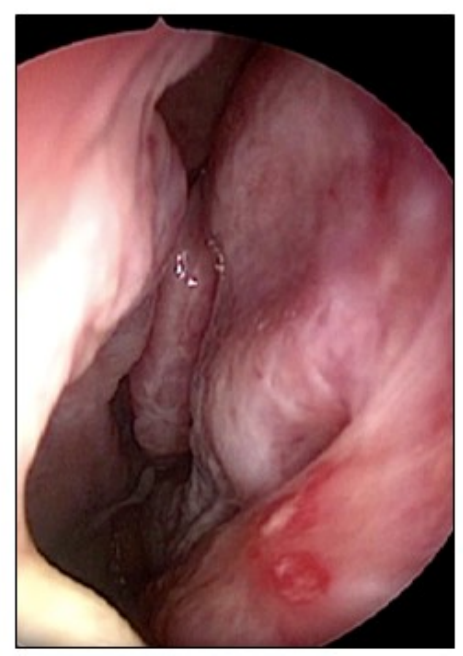

Figure 2: The presence of telangiectatic lesions on the right anterior part of nasal septum 


\section{DISCUSSION}

HHT is also known as Osler-Weber-Rendu Syndrome first described by Sir William Osler in 1901. It is an autosomal dominant and non-sex linked inherited disorder. Frequency varies from country to country but overall prevalence of HHT in Western countries is 1 in 5000 to 8000 .

Clinical diagnosis of HHT is made base on Curacao criteria which consist of 1) Epistaxis (spontaneous and recurrent), 2) Telangiectases (multiple at characteristic sites- lips, oral cavity, finger and nose), 3) Visceral lesions (such as gastrointestinal telangiectasia with or without bleeding, pulmonary AVM, cerebral AVM and spinal AVM) and 4) family history (a first degree relative with HHT). ${ }^{2}$ Presence of three criteria indicate a definite diagnosis, two criteria would lead to a possible or suspected cases. All our cases had at least three positive criteria (recurrent epistaxis, gastrointestinal telangiectasia, cutaneous telangiectasia and family history) fulfilling a definite diagnosis of HHT. Recently the spectrum, of disease within the HHT umbrella has extended beyond telangiectasia/AVM with pulmonary arterial hypertension, juvenile polyposis and high cardiac output failure secondary to hepatic AVM among the newly recognized nonCuracao features. ${ }^{3}$

Gene mutation plays a role in the pathogenesis of HHT. Based on mutation of genes, five types of HHT had been identified. The two most common types are HHT1 and HHT 2. The two genes identified endoglin in chromosome 9 and ACRVL1/AK1 in chromosome 12. The clinical features of HHT 1 and HHT 2 are similar but lower penetrance and later onset is observed in HHT 2 and higher frequency of pulmonary AVM and cerebral AVM is observe in HHT $1 .{ }^{4,5}$ With this we conclude that all our cases is HHT 2 even though no genetic studies had been done.

We have four cases of HHT under our follow up. $75 \%$ are men and $25 \%$ are woman. The mean age of onset of epistaxis is 37 years old. The mean age of presentation to our center is $\mathbf{5 8 . 7 5}$ years old. The late presentation is because the patients tend not to seek treatment when the epistaxis is mild. In literatures, the sexual predilection and age of presentation varies among all centres as this is a rare disease.
Generally there is no agreed consensus on imaging studies to detect the presence of other visceral AVM such as brain, lung and liver. There is a role of screening for visceral AVM in aiding towards the diagnosis of HHT if the patient is symptomatic. In our patients, OGDS was performed as both patients complained of gastritis symptoms. There are studies that recommended pulmonary screening in all patients with suspected or confirmed HHT in view of majority of pulmonary AVM (PAVM) is undiagnosed before complications such as PAVM-induced ischaemic stroke. ${ }^{6,7}$ All of our patients were screened for PAVM and visceral AVM.

The severity and frequency of epistaxis in HHT varies among patients. In general only $1 / 3$ rd of patient will have frequent severe epistaxis requiring multiple hospital admissions and blood transfusion. ${ }^{8,9,10}$ A variety approaches of surgical treatment modalities which include electrocauterization, microembolization, septodermoplasty or nostril closure surgery had been mentioned depending on the severity of the epistaxis. Recently, medical treatment with application of estriol over the nasal mucosa to induce squamous metaplasia and usage of silicone swab to occlude the nostril as an alternative to surgical nostril closure had been mentioned in literatures. We have two patients underwent septodermoplasty, the outcome of surgery is satisfactory. In all our cases, epistaxis was able being control with good outcome with a combination of septodermoplasty and electrocauterization using bipolar diathermy of telangiectasia spots over the nasal mucosa.

In conclusion, HHT often presents with recurrent epistaxis. A diagnosis of HHT should be suspected if the patient had mucocutaneous telangiectasia lesions over the skin, oral cavity and lip, fingers and nails. An early otorhinolaryngology referral should be done for further assessment to prevent morbidity and mortality among patient with HHT. In our center we advocate a combination of septodermoplasty and electro-cauterization of telangiectasic vessels as the main treatment modality as it shows good outcome. 
Table 1: Summary of 4 HHT cases

\begin{tabular}{|c|c|c|c|c|}
\hline $\begin{array}{l}\text { Overview } 1 \\
\text { Cases }\end{array}$ & Case 1 & Case 2 & Case 3 & Case 4 \\
\hline Age & 60 & 58 & 65 & 69 \\
\hline Gender & Female & Male & Female & Male \\
\hline Ethnicity & Chinese & Chinese & Chinese & Chinese \\
\hline $\begin{array}{l}\text { Criteria for } \\
\text { diagnosis }\end{array}$ & $\begin{array}{l}\text { Recurrent epistaxis, } \\
\text { gastrointestinal } \\
\text { telangiectasia, } \\
\text { cutaneous } \\
\text { telangiectasia }\end{array}$ & $\begin{array}{l}\text { Recurrent epistaxis, } \\
\text { gastrointestinal } \\
\text { telangiectasia, cutaneous } \\
\text { telangiectasia and family } \\
\text { history (mother and } 2 \\
\text { siblings) }\end{array}$ & $\begin{array}{l}\text { Recurrent epistaxis, } \\
\text { gastrointestinal } \\
\text { telangiectasia, cutaneous } \\
\text { telangiectasia and family } \\
\text { history (mother and } \\
\text { younger brother }\end{array}$ & $\begin{array}{l}\text { Recurrent epistaxis, } \\
\text { gastrointestinal } \\
\text { telangiectasia, } \\
\text { cutaneous } \\
\text { telangiectasia }\end{array}$ \\
\hline OGDS findings & $\begin{array}{l}\text { Multiple telangiectatic } \\
\text { spots in the stomach }\end{array}$ & $\begin{array}{l}\text { Multiple telangiectatic } \\
\text { spots in the stomach }\end{array}$ & Normal findings & $\begin{array}{l}\text { Multiple } \\
\text { telangiectatic spots } \\
\text { over antrum of the } \\
\text { stomach }\end{array}$ \\
\hline $\begin{array}{l}\text { Computed to- } \\
\text { mography scan } \\
\text { of thorax }\end{array}$ & Normal findings & Normal findings & Normal findings & Normal findings \\
\hline $\begin{array}{l}\text { Blood } \\
\text { transfusion }\end{array}$ & Once & Once & No & Multiple \\
\hline \multirow[t]{3}{*}{$\begin{array}{l}\text { Surgical } \\
\text { intervention }\end{array}$} & \multirow[t]{3}{*}{$\begin{array}{l}\text { Electocauterization of } \\
\text { the telangiectatic } \\
\text { spots in the nose }\end{array}$} & $\begin{array}{l}\text { Electocauterization of the } \\
\text { telangiectatic spots in the } \\
\text { nose }\end{array}$ & Left septodermoplasty & $\begin{array}{l}\text { Electocauterization } \\
\text { of the telangiectatic } \\
\text { spots in the nose }\end{array}$ \\
\hline & & \multirow{2}{*}{$\begin{array}{l}\text { Endoscopic clipping of } \\
\text { telangiectatic spot in the } \\
\text { stomch }\end{array}$} & & $\begin{array}{l}\text { Right septodermo- } \\
\text { plasty }\end{array}$ \\
\hline & & & & $\begin{array}{l}\text { Left } \\
\text { septodermoplasty } \\
\text { (twice) }\end{array}$ \\
\hline Progress & $\begin{array}{l}\text { Mild epistaxis, do not } \\
\text { require blood } \\
\text { transfusion }\end{array}$ & $\begin{array}{l}\text { Mild epistaxis, do not re- } \\
\text { quire blood transfusion }\end{array}$ & No epistaxis & $\begin{array}{l}\text { Mild epistaxis, do not } \\
\text { require blood trans- } \\
\text { fusion }\end{array}$ \\
\hline
\end{tabular}

\section{REFERENCES}

1. Plachau $\mathrm{H}$, de Chadarevian JP, Bideau A, et al. Age related clinical profile of hereditary hemorrhagic telangiectasia in an epidemiologically recruited population. Am J Med Genet. 1989; 32:291-7.

2. Haitjema T, Westermann CJ, Overtoom TT, et al. Hereditary hemorrhagic telangiectasia (Osler -Weber-Rendu disease) new insights in pathogenesis, complications, and treatment. Arch Intern Med 1996; 156:714-719.

3. Claire L. Shovlin. Hereditary haemorrhagic telangiectasia: Pathophysiology, diagnosis and treatment. Blood Reviews 2010; 24:203-219.
4. Kjeldsen $A D$, Møller TR, Brusgaard $K$, et al. Clinical symptoms according to genotype amongst patients with hereditary haemorrhagic telangiectasia. J Int Med 2005; 258:349-355.

5. Letteboer TGW, Mager JJ, Snijder RJ, et al. Genotype-phenotype relationship in hereditary haemorrhagic telangiectasia. J Med Genet 2006; 43:371-377.

6. Shovlin CL, Letarte $M$. Hereditary haemorrhagic telangiectasia and pulmonary arteriovenous malformations: issues in clinical management and review of pathogenic mechanisms. Thorax 1999; 54:714-729. 
7. Cottin V, Plauchu H, Bayle J-Y, Barthelet M, Revel D, Cordier JF. Pulmonary arteriovenous malformations in patients with hereditary hemorrhagic telangiectasia. Am J Respir Crit Care Med 2004; 169:994-1000.

8. McCaffrey TV, Kern EB, Lake CF. Management of epistaxis in hereditary hemorrhagic telangiectasia: review of 80 cases. Arch Otolaryngol 1977; 103:627-630.

9. Hitchings AE, Lennox PA, Lund VJ, Howard DJ. The effect of treatment for epistaxis secondary to hereditary hemorrhagic telangiectasia. Am J Rhinol. 2005; 719(1):75-8.

10. Lennox PA, Hitchings AE, Lund VJ, Howard DJ. The SF-36 health status questionnaire in assessing patients with epistaxis secondary to hereditary hemorrhagic telangiectasia. Am J Rhinol 2005; 19(1):71-74. 
